\title{
IMPROVING LEARNING OUTCOMES OF BASIC ACCOUNTING IN X GRADERS THROUGHT COOPERATIVE LEARNING MODELS IN JIGSAW TYPE
}

\author{
PENINGKATAN HASIL BELAJAR SISWA KELAS X PADA MATA PELAJARAN \\ AKUNTANSI DASAR MELALUI MODEL PEMBELAJARAN KOOPERATIF TIPE \\ JIGSAW
}

By:

Risa Novita Wati

Accounting Education Department Yogyakarta State University

novita.risa@gmail.com

Adeng Pustikaningsih

Lecturer of Accounting Education Department Yogyakarta State University

\begin{abstract}
This study aims to: find out the differences in learning outcomes of Basic Accounting in $\mathrm{X}$ Graders at SMK Negeri 1 Depok Academic Year 2018/2019 before and after the application of the Jigsaw Cooperative Learning Models. This research is a Quasi-Experimental study. Data collection techniques using simple random sampling for the selection of control classes and experimental classes that will be drawn randomly. The subjects of this study were students of class X AKL 1 and X AKL 3 at SMK Negeri 1 Depok. The design of data collection in this study uses the Pretest-posttest control group design model. Data analysis was performed using descriptive analysis and hypothesis testing. The results of the study are: (1) the pre-test learning outcomes in the control class obtained an average value of 71.376, the highest value of 90 and the lowest value of 50. While the pre-test scores in the experiment class obtained an average value of 71.8, the highest value of 90 and the lowest value of 50 (2) post-test learning outcomes in the control class obtained an average value of 71.433 , the highest value of 83 and the lowest value of 60 . While the post-test in the experiment class obtained an average of 80.733 with the highest value of 90 and the lowest value of 67 . (3) Based on the results of the t-test that is $6.122 \geq 2.00172$ or $t_{\text {count }}>t_{\text {table }}$ on the results of the post-test of the experiment group and the control group, it can be concluded that there are significant differences between the results of the control class and the experiment class so that there is a significant increase the application of Cooperative Learning Models in Jigsaw type in Basic Accounting subjects to the learning outcomes of X Accounting Graders.
\end{abstract}

Keywords: Jigsaw, Learning Outcomes, Basic Accounting

\section{Abstrak}

Penelitian ini bertujuan untuk: mengetahui perbedaan hasil belajar siswa kelas X Akuntansi pada Mata Pelajaran Akuntansi Dasar di SMK Negeri 1 Depok Tahun Ajaran 2018/2019 sebelum dan setelah penerapan model pembelajaran Cooperative Learning tipe Jigsaw. Penelitian ini merupakan penelitian Quasi- Experiment Design. Teknik pengambilan data menggunakan simple random sampling untuk pemilihan kelas control dan kelas eksperimen yang akan diundi secara acak. Subjek penelitian ini adalah siswa kelas X AKL 1 dan X AKL 3. Desain pengambilan data pada penelitian ini menggunakan model Pretest-posttest control 
group design. Analisis data yang dilakukan menggunakan analisis deskripsi dan uji hipotesis. Hasil penelitian menunjukkan bahwa: (1) hasil belajar pre-test pada kelas kontrol diperoleh nilai rata-rata 71,367, nilai tertinggi 90 dan nilai terendah 50. Sedangkan pada kelas eksperimen diperoleh nilai rata-rata sebesar 71,8, nilai tertinggi 90 dan nilai terendah 50 (2) hasil belajar post-test pada kelas kontrol diperoleh nilai rata-rata 71,433, nilai tertinggi 83 dan nilai terendah 60. Sedangkan pada kelas eksperimen diperoleh rata-rata sebesar 80,733 dengan nilai tertinggi 90 dan nilai terendah 67. (3) Berdasarkan hasil uji t-test yaitu 6,122 $\geq$ 2,00172 atau thitung $>t_{\text {tabel }}$ pada hasil post-test kelompok eksperimen dan kelompok kontrol, maka dapat disimpulkan terdapat perbedaan yang signifikan antara hasil post-test kelas kontrol dan kelas eksperimen sehingga dinyatakan ada peningkatan yang signifikan dalam penerapan model pembelajaran Cooperative Learning tipe Jigsaw terhadap hasil belajar siswa kelas X Akuntansi pada mata pelajaran Akuntansi Dasar.

\section{Kata Kunci: Jigsaw, Hasil Belajar, Akuntansi Dasar}

\section{INTRODUCTION}

The world of education and science is increasingly fast and obvious development, both within the scope of the country and in the world. The development of science requires individuals to be active in following any ongoing scientific developments. It will create innovations in the educational process, therefore with the renewal in the field of education is expected to produce models and processes of teaching and learning activities in the classroom so that it can increase motivation, activeness and creative thinking of students. Education cannot be separated from the development process that is directed and aims to develop quality human resources. This is in accordance with the objectives of national education, that national education aims to educate the nation's life and develop human beings as a whole, in addition to having faith and devotion to God Almighty and physically and mentally healthy, also having abilities and also skills.

The goals of education in Indonesia have not been well achieved. This is caused by obstacles in the implementation of education. These obstacles come from within (internal) and from outside (external) education. External barriers are conditions which encompass and influence the condition of national education. Meanwhile, internal obstacles are the real condition of education which is the source of problems or which is the problem of education from within (Muhammad Rifai 2011: 54).

Obstacles that occur in the world of education will cause the quality of education in Indonesia to be low. Based on research conducted by the Indonesian Education Monitoring Network (JPPI) published in 2017 shows that Indonesia is ranked 7th out of 14 countries chosen randomly with a score of $77 \%$. These results indicate the quality of education in Indonesia is inadequate. In addition, the quality of education in Indonesia is below the Philippines and Ethiopia with scores of $81 \%$ and $79 \%$. In a study conducted by JPPI also mentioned that of the 5 indicators measured, there were 3 indicators that were still low, namely regarding the quality of teachers (availability), schools were not child friendly (acceptability) and access for marginal groups (adaptability). The quality of education in Indonesia can be improved in a number of ways and it requires the involvement of various parties such as school principals, teachers, students, curriculum and network of cooperation between schools and the community. Of the several parties involved, the principal and teachers are those who have a great responsibility towards improving the quality of education in schools.

Vocational High Schools (SMK) are educational institutions or providers that emphasize the ability of students to do 
certain types of work, which aims to prepare students for direct employment by developing professional attitudes. Teachers are considered as the spearhead of education in schools. The teacher is one of the people who is closest to students when they are at school, so the teacher is considered to understand and know the characteristics of the students. In connection with these conditions the teacher's role is needed to develop the potential of students by doing various ways to create active, innovative, and creative learning.

Learning strategy is one of the things that is very influential on the success of teachers in teaching, with the learning strategies used by teachers can help students in understanding the subject matter delivered by educators. One learning model that can help students to be active and not feel difficulties in the accounting learning process is the cooperative learning strategy. In his research Robert E. Slavin (2014: 785) suggested that "cooperative learning refer to instructional methods in which students work in small groups to help each other learns. Four major theoretical perspectives on the achievement of the effects of cooperative learning are reviewed: Motivational, social cohesion, developmental, and cognitive elaboration". Miftahul Huda (2012: 31) defines cooperative learning as the formation of small groups of students who are required to work together and enhance the learning of other students. Meanwhile, Zakaria and Iksan (2007), as quoted by Mehta and Kulshrestha (2014: 2), "believed that cooperative learning is grounded in the beliefs that learning is most effective when students are actively involved in sharing ideas and working cooperatively to complete academic tasks".

The Jigsaw type cooperative learning model was developed and tested by Elliot Arronson and his colleagues at the University of Texas, and later adapted by Slavin and his colleagues at John Hopkin University (Sugianto, 2010: 45). Jigsaw is one of the most flexible cooperative methods (Slavin, 2005: 246). Jigsaw type cooperative learning model is an interesting strategy to use if the material to be studied can be divided into sections and the material does not require the order of delivery. Meanwhile, according to Isjoni (2010: 77) explains that cooperative learning jigsaw is one of cooperative learning that encourages students to be active and help each other in mastering subject matter to achieve maximum achievement. Shan-Ying $\mathrm{Chu}$ (2014: 166) also stated "empirical findings support that Jigsaw cooperative learning method benefits students' academic achievement and knowledge retention in terms of the increase in mean scores and the decrease in standard deviation of scores".

Accounting is subject matter that is always changing along with the times, regulations and policies that apply are always adapted to the current situation, so that a teacher must be able to deliver the material according to the actual situation in an update so it is expected that knowledge delivered to students also in accordance with the development of science regarding accounting at this time. Success in teaching and learning activities can be measured by looking at the value obtained by students. With the implementation of the Minimum Mastery Criteria (KKM) can be used as a basis for measuring the ability of students, whether they have achieved the KKM value or have not participated in teaching and learning activities in the classroom.

The result of this study are reinforced by the research of Riskiyah (2017) with the title "Pengaruh Model Pembelajaran Cooperative Learning Tipe Jigsaw pada Mata Pelajaran Dasar Desain Terhadap Hasil Belajar Siswa Kelas X di SMK N 3 Klaten". The results of this study indicate that: (1) Pre-test learning outcome in the control class obtained an average value of 73.01 , the highest score of 82 and the lowest score of 62, students who reached KKM were 23 students and students whose grades below KKM were 16 students. While the 
pre-test scores in the experimental class obtained an average value of 74.5 , the highest score of 85 and the lowest score of 64 , students who reached KKM as many as 25 students and students whose grades below the KKM were 14 students. (2) Posttest learning outcomes in the control class obtained an average value of 78.29 , the highest score of 90 and the lowest score of 70, students who reached KKM as many as 34 students and students whose grades below the KKM were 5 students. While the post-test in the experimental class obtained an average of 86.42 with the highest score of 98 and the lowest score of 75 , students who reached KKM were 39 students. (3) There is an influence of the use of the Jigsaw Cooperative Learning model of Basic Design Subjects in $\mathrm{X}$ Graders Learning Outcomes at SMK N 3 Klaten. Based on the results of the t-test that is $6.554 \geq 1.991$ or $t_{\text {count }}>t_{\text {table }}$ on the results of the post-test of the experiment group and the control group.

This research also reinforced by the result of Tri Yudono (2013) with the title "Perbedaan Model Pembelajaran Kooperatif Tipe Jigsaw dan STAD Terhadap Prestasi Belajar Siswa Pada Mata Pelajaran Pemeriharaan Kelistrikan Kendaraan Ringan Kelas XI Jurusan Otomotif SMK Negeri 2 Wonosari Tahun Pelajaran 2015/2016". The results showed that there were differences in the average learning achievement of the Jigsaw class posttest of 81.20 and the STAD class of 77.07 from the hypothesis test found that $\mathrm{t}_{\text {count }}$ was greater than $\mathrm{t}_{\text {table }}\left(\mathrm{t}_{\text {count }}=3.2354>\right.$ table $=2.001717)$. The results of increased learning achievement, can be seen from the Gain value of each class, namely the Jigsaw 0.784 class included in the high category and the STAD class 0.668 included in the medium category, so that the class using the Jigsaw method has a higher increase in learning outcomes compared to the class using the method STAD.

This research is also supported and conducted by Lely Afreyanti (2013) entitled "Efektivitas Penggunaan Metode
Cooperative Learning Tipe Jigsaw untuk Meningkatkan Hasil Belajar Persiapan Pengolahan pada Siswa Kelas X SMK Negeri 4 Yogyakarta". The results showed: (1) learning outcomes with the lecture method in the eyes of the Preparatory Processing course of X Catering Graders 2 students of SMK N 4 Yogyakarta for the pre-test scores of the control class 8.33861 and for the post-test scores of 8.4197 there was an increase of 0.1056 (2) the results of competency learning to do basic preparation of food processing after the use of Jigsaw cooperative learning method in X Catering Graders 1 students of SMK N 4 Yogyakarta for the experimental class pre-test scores of 8,2833 and for the 9,9500 post-test scores contained an increase of 0.6667 (3) the results of the t-test showed that there were significant differences between students who learned the lecture method and students who learned using cooperative jigsaw.

The next relevant research is supported and reinforced by Nikmah Khoiroh (2011) with the title "Efektivitas Model Pembelajaran Kooperatif Tipe Jigsaw Berbantuan Macromedia Flash Terhadap Prestasi Belajar Siswa Kelas XI IPS pada Mata Pelajaran Akuntansi Pokok Bahasan Jurnal Penyesuaian di SMA N 2 Ungaran Tahun Ajaran 2010/2011". Research Results Show: (1) The results of the study obtained an average student learning achievement using a cooperative learning model of jigsaw type assisted by macromedia flash increased by 28.44 is an initial average of 50.81 to 79.25 and higher than the increase in learning achievement in students with conventional learning models that only increased by 21.34 is from an average of 51.28 to 72.62 . Independent sample $t$ test results obtained a significant value of 0.001 so that $\mathrm{H}_{1}$ is accepted, which means there is a significant difference between the average learning achievement of students who use the Jigsaw type cooperative learning model with students who use conventional learning models that is 79.52 compared to 72,62 . 
This research has implications, namely Learning model application Cooperative Learning Type Jigsaw in SMK Negeri 1 Depok Yogyakarta lead to improvements in student learning outcomes and provide the prospect of supporting the implementation of the curriculum 2013. Learning Model Cooperative Learning Type Jigsaw encourage students play an active role in the learning process, cooperate and assist in the completeness material, develop insight and thinking activities of students through the realm of cognitive, affective, and psychomotor, improve social relationships and respect the opinions of others. This research was conducted at SMK Negeri 1 Depok with the reasons: (1) Student Learning Outcomes of $\mathrm{X}$ Accounting Graders is still not optimal, because not all students meet the KKM value. This is evidenced by the results of daily tests of $66,67 \%$ do not meet the Minimum Mastery Criteria. (2) Only a few students are active when teaching and learning activities take place. (3) There are some students who have low learning motivation. (4) How to teach teachers by using the lecture method that is often used by accounting teachers during learning makes students get bored quickly in taking accounting lessons in the classroom. (5) The teacher often leaves the class due to additional teacher assignments. (6) The teacher is still dominant in learning in the classroom.

\section{RESEARCH METHOD \\ Research Design}

Type of research is using the method of research experiment with designs QuasiExperimental Design or also can be referred to as a design experiment apparent. The use of quasi experiment in this research is because the research subject is human who can not be controlled and manipulated the data. The Quasi Experimental Design form used is the non-equivalent control group design. Techniques of data retrieval using simple random sampling for the election of class control and class of experiments that will be drawn randomly.

In a research experiment, the grade control using methods of learning in conventional (lecture, hands-on learning) while class experiments using methods of learning cooperative type of Jigsaw. Design data collection on research is using a model pretest-posttest control group design, in which the model is done by giving the test early in the second grade before given treatment to measure the condition early the next in class experiments are given treatment and the grade control is not given treatment. After completion given treatment and then the two classes are given tests come back as a posttest.

\section{Place and Time of Research}

This research was conducted at SMK Negeri 1 Depok, Yogyakarta, located at Ring Road Utara Streat, Maguwoharjo, Depok, Sleman, Yogyakarta. The time of research in the even semester on May of the Academic Year 2018/2019.

\section{Research Subject}

The population in this study were students of $\mathrm{X}$ Accounting Graders at SMK Negeri 1 Depok totaling 96 are divided into three classes, namely AKL1, AKL2, and AKL3. The sample is part of the number and characteristics possessed by the population. In this study the sampling technique used was Simple Random Sampling. Determination of sampling is done by composing a sampling frame, which consists of class X AKL1, X AKL2, and X AKL3. The next procedure is to determine the number of samples to be taken. This research will take two classes from three classes at SMK Negeri 1 Depok. The next step is determining the sample selection tool. The determination of two classes that will be used in this study uses a lottery method to determine one control class and one experiment class. 


\section{Procedure}

One effort to design a pleasant learning climate in the classroom so as to increase student activity is the use of attractive learning models. One type of lesson model is Cooperative Learning Model in Jigsaw Type. Cooperative Learning Model in Jigsaw Type in this study applied the experiment class. The experiment class is a class that is given treatment. Meanwhile, to determine its effect in learning, control classes (classes that are not given treatment) are applied direct learning models as a comparison of the effectiveness of these models. The initial conditions of the control class and the experiment class are in a balanced condition for learning outcomes. If the student is given the Cooperatif Learning Model in Jigsaw Type acquire learning outcomes above average, meaning in the world of true education-right helpful. However, if students who are not given a Jigsaw Type Cooperative Learning Model also receive the same learning outcomes, it means that the Jigsaw Type Cooperative Learning Model is of little use in the world of education.

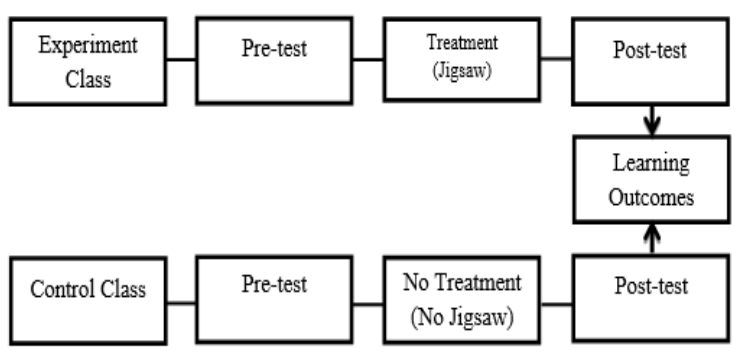

Figure 1. Plot of Research Framework

\section{Data, Instruments, and Data Collecting Technique}

a). Data

This research used test instrument as data collecting Technique. The test used by researchers in the form of pre-test and post-test questions. This test is used to measure student learning outcomes on the cognitive aspects of students. Pre-test is used to determine the initial ability of students before being given treatment while the post-test is used to determine student learning outcomes after treatment. b). Data Analysis Technique

The data analysis technique used in this research is descriptive statistic and hypothesis test. The descriptive statistic using descriptive analysis techniques in the form of histograms, measurement of central symptoms through mode, median, mean, measurement of group variations through ranges, standard deviations, and frequency distribution.

Hypothesis test used in this study is the t-test. T-test is one of the parametric statistical hypothesis tests that are used to compare the average of two samples if the data is in the form of intervals or ratios. This t-test was conducted to determine whether there were differences or not between the learning outcomes of the experimental group and the control group. T-test in this study was carried out twice. The first test$t$ for data pre-test on two groups of experiments and controls are intended to determine the initial results of research subject. Second, to test post-test data on two groups that are intended to determine learning outcomes after being given treatment.

\section{RESEARH RESULT AND DISCUSSION Cooperative Learning Models in Jigsaw Type}

a) Definition of Jigsaw Type

The Jigsaw method was first developed by Aronson. This method has two additional versions, Jigsaw II (Slavin) and Jigsaw III (Kagan). In the Jigsaw type cooperative learning model, students are placed in small groups consisting of 5 members. Each group was given information that discussed one topic from their current subject matter. From the information provided in each of these groups, each member must learn different parts of the information (Miftahul Huda 2012: 120). According to Isjoni (2010: 54) Jigsaw type cooperative learning is one type of cooperative 
learning that encourages students to be active and help each other in mastering subject matter to achieve maximum achievement. As stated by Juweto G. A (2015: 33) said that "jigsaw co-operation teaching-learning strategy is a teaching and learning strategy that promotes motivation in learning, positive attitudes and develop interpersonal skills and increases student's achievement".

b) The Steps of the Jigsaw Type

According to Riyanto (2010: 271 272) the steps of the Jigsaw cooperative learning model are as follows:

(1) Students are grouped into 4 team members.

(2) Each person in the team is given a different part of the material.

(3) Each person on the team is given the assigned part of the material.

(4) Members from different teams who have studied the same section/subchapter meet in a new group (expert group) to discuss their section/subchapter.

(5) After finishing the discussion as an expert team each member returns to the original group and alternately teaches their teammates about the section/sub-chapter they are mastering and each other member listens intently.

(6) Each expert team presents the results of the discussion.

(7) The teacher gives an evaluation.

(8) Closing.

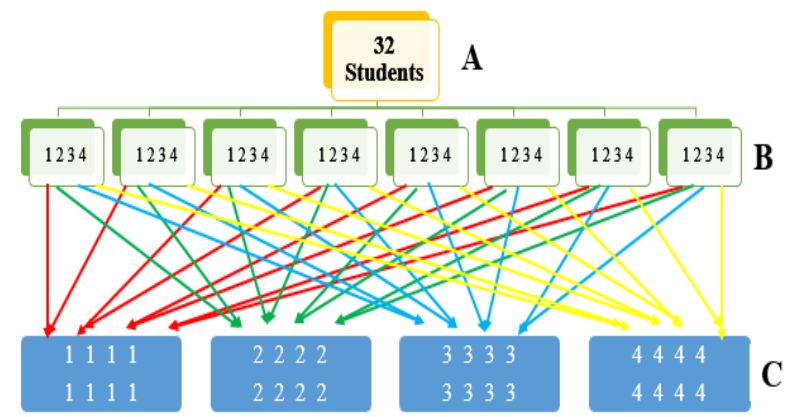

$\begin{array}{lllllllllll}1234 & 1234 & 1234 & 1234 & 1234 & 1234 & 1234 & 1234 & \text { B }\end{array}$

$\mathrm{A}=$ Classical $\mathrm{B}=$ Origin Group C = Expert Group

Figure 2. Flowchart of Jigsaw Type Implementation

The Experiment class consisted of 32 students divided into 8 groups so that each group consisted of 4 members. The group is named as the origin group consisting of several expert groups formed by taking into account the diversity and background of students. Each of the origin group members is given the responsibility to study the topics assigned to each group member. The subject that will be discussed is Basic Accounting on the subject matter of the Adjusting Journal, where the material is divided into 4 sub-chapters consisting of the understanding and basic concept of the adjusting journal, types of adjustment journals, adjusting journal transactions, and preparation of the adjusting journal. After each origin group member gets the assignment, they will meet with the same topic in the expert group to discuss and understand the material assigned to each group member and help each other to learn the topic. The teacher's role in the discussion process is to facilitate and motivate the members of the expert group so that it is easy to understand the material provided. After the discussion is over, the expert group members return to the origin group and teach their group friends what they have got during the meeting with the expert group. The expert groups must be able to share the 
knowledge gained during discussions in the expert group, so that knowledge can be received by each member in the original group.

\section{Descriptive Analysis}

a) Learning Outcomes of Basic Accounting Subject Before Implementing the Cooperative Learning Model in Jigsaw Type for X Accounting Graders at SMK Negeri 1 Depok

This research phase provides a pre-test of the control class and the experiment class. Pre-test is a test used to determine student learning outcomes before applying Cooperative Learning Model in Jigsaw type. Based on statistical calculations, the highest value of the control class is 90 and the experiment class is 90 . The lowest value is 50 in the control class and the lowest value is 50 in the experiment class. The mean value was 71.376 , the median value was 71.5 , the mode value was 73 and the standard deviation value was 8.079 in the control class. Experiment Class obtained a mean value of 71.8 , the median value of 71.5 , the mode value of 70 and a standard deviation of 7.617.

Based on the primary data has been processed, the histogram can be described as follows:

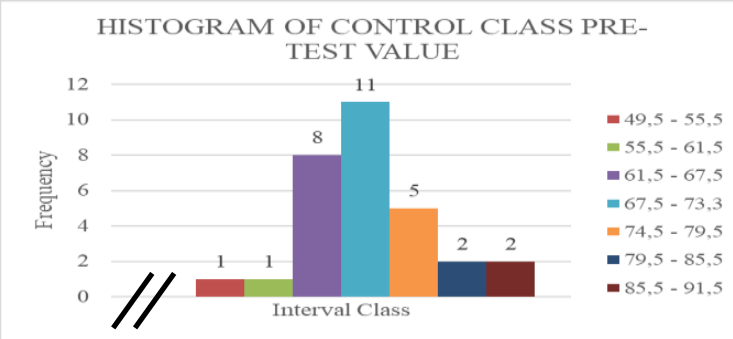

Figure 3. Histogram Frequency

Distribution of Control Class Pre-Test Values

While the results of the calculation of the primary data has been processed of pre-test values in the experiment class, the histogram can be described as follows:

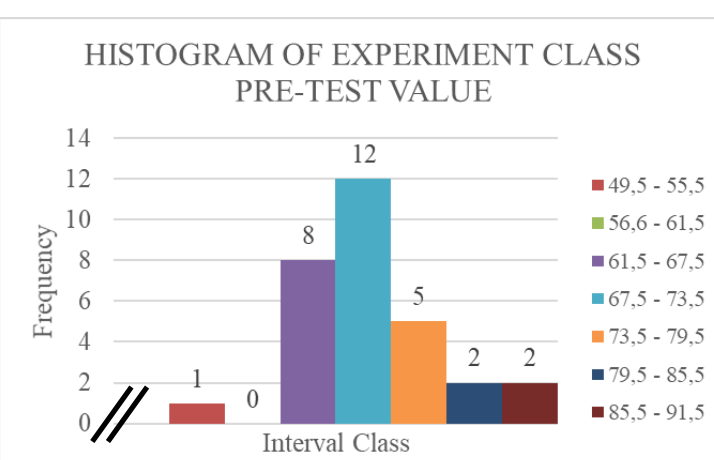

Figure 4. Histogram Frequency

Distribution of Control Class Pre-Test Values

Limit criteria for completeness minimum (KKM) SMK N 1 Depok to subjects Basic Accounting a dalah 74 . From the results of the control class pretest scores totaling 30 students, there were 21 students whose grades were below the KKM, and there were 9 students who passed the KKM. While The results of the pre-test scores in the experiment class totaling 30 students, there were 21 students whose grades were below the KKM, and 9 students passed the KKM. The results of the Basic Accounting value completeness category in the control class and Experiment Class can be seen in Table 1 below.

Table 1. Completeness Category Table Control Class and Experiment Class Pre-test Value

\begin{tabular}{|c|c|c|c|c|}
\hline \multirow{2}{*}{ No } & \multirow{2}{*}{ Category } & Desc & Control class & $\begin{array}{c}\text { Experiment } \\
\text { class }\end{array}$ \\
\cline { 4 - 5 } & & & 21 & 21 \\
\hline 1. & Not finished yet & Value $<74$ & 9 & 9 \\
\hline 2. & Complete & Value $\geq 74$ & 30 & 30 \\
\hline \multicolumn{3}{|c|}{ Total } & & 30 \\
\hline
\end{tabular}

Resource: Primary data that has been processed

Based on the completeness category table, then to see the percentage of completeness of the pre-test scores of the control class and experiment class students using bar charts. The results of the percentage of completeness of the pre-test value of the control class and the 
experiment class can be seen in the following Figure 5.

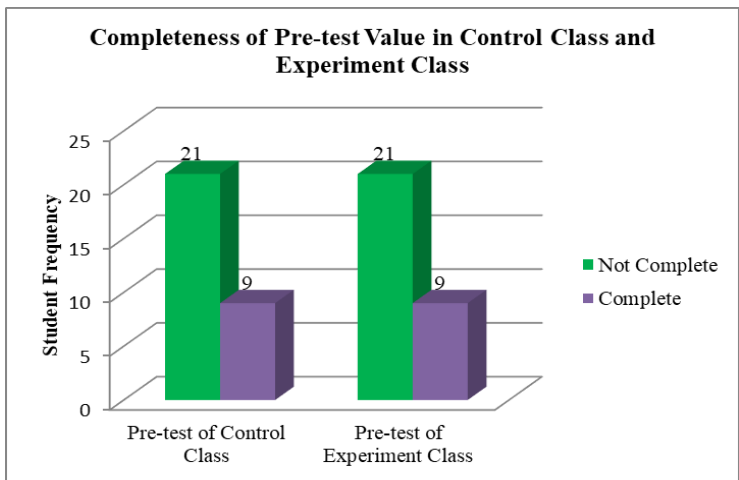

Figure 5. Completeness of the Control and Experiment Class Pre-test Values

b) Learning Outcomes of Basic Accounting Subject After Implementing the Cooperative Learning Model in Jigsaw Type for X Accounting Graders at SMK Negeri 1 Depok

The final stage of the study of each class both the control class and the experiment class were given treatment. Treatment were performed on experiment class using Cooperative Learning Model in Jigsaw Type and learning directly in the control class. In the learning activities in the second grade class the final test (post-test) was conducted which aimed to determine student learning outcomes after the experimental method was applied in the form of a Cooperative Learning model in Jigsaw type. Total subject of research on carp ing each group numbered 30 students.

Based on statistical calculations, the highest value of the control class is 83 and the experiment class is 90 . Values as low as 60 in the control class and the lowest value of 67 in the experiment class. The mean value of 71.433 , a median value is 73 , the value of the mode is 73 and the standard deviation value of 5.992 in the control class. The experiment class obtained a mean value of 80.733 , a median value of 81.5 , a mode value of 83 and a standard deviation value of 5.883 .
Based on the primary data has been processed, the histogram can be described as follows:

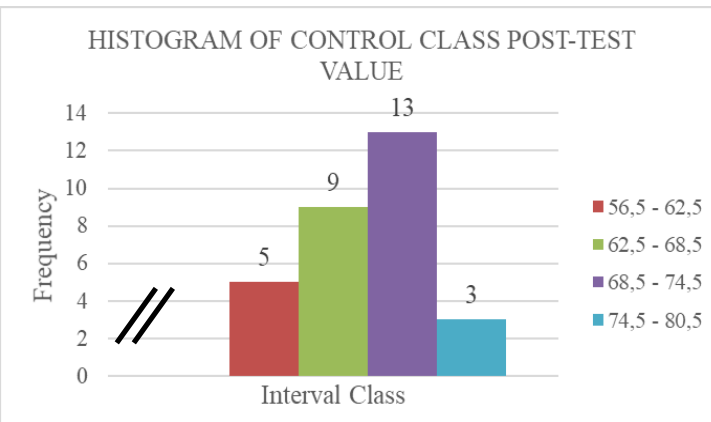

Figure 6. Histogram Frequency Distribution of Control Class Post-Test Value

While the results of the calculation of the primary data has been processed of pre-test values in the experiment class, the histogram can be described as follows:

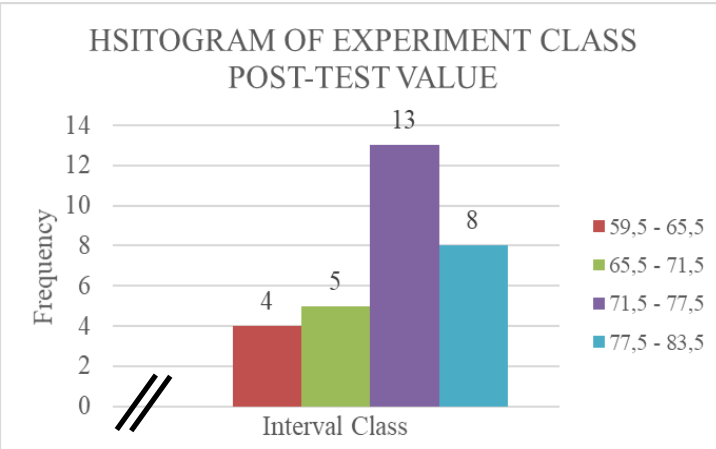

Figure 7

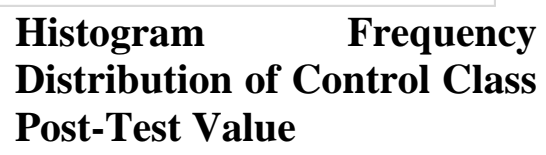

Limit criteria for completeness minimum (KKM) SMK N 1 Depok of Basic Accounting is 74. From the results of the post- test scores of the control class totaling 30 students, there were 21 students whose grades were below the $\mathrm{KKM}$, and there were 9 students who passed the KKM. While The results of the post- test scores in the experiment class totaling 30 students, there were 4 students whose grades were below the $\mathrm{KKM}$, and 26 students passed the KKM. The results of the Basic Accounting value 
completeness category in the control class and Experiment Class can be seen in Table 2 below.

Table 2. Completeness Category Table Control Class and Experiment Class Post-test Value

\begin{tabular}{|c|c|c|c|c|}
\hline \multirow{2}{*}{ No } & \multirow{2}{*}{ Category } & Desc & \multicolumn{2}{|c|}{ Total } \\
\cline { 4 - 5 } & & & Control class & $\begin{array}{c}\text { Experiment } \\
\text { class }\end{array}$ \\
\hline 1. & Not finished yet & Value $<74$ & 21 & 4 \\
\hline 2. & Complete & Value $\geq 74$ & 9 & 26 \\
\hline \multicolumn{3}{|c|}{ Total } & 30 & 30 \\
\hline
\end{tabular}

Resource: Primary data that has been processed

Based on the thoroughness of the category table, and then to see the percentage of completeness value of posttest control class and experiments class using bar charts. The percentage of category completeness value of post -test control group and the experimental class can be seen in Figure 8 below.

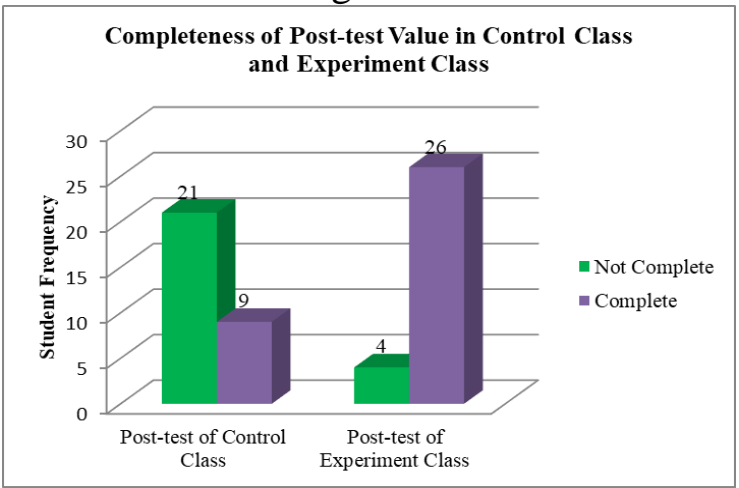

Figure 8. Completeness of the Control and Experiment Class Post-test Values

\section{Hypothesis Test}

a) T-Test Pre-Test Control Class and Experiment Class

The hypothesis used in this test is:

$\mathrm{Ha}$ : There is a significant difference between the results of the pre-test control class and the experiment class

Ho : There is no significant difference between the results of the pre-test control class and the experiment class

If the value of $t_{\text {count }} \geq$ from $\mathrm{t}_{\text {table }}$, then $\mathrm{Ha}$ is accepted and Ho is rejected or there is a significant difference between the pretest results of the control class and the experimental class while if the value of $t_{\text {count }} \leq$ from $t_{\text {table }}$ then Ho is accepted and $\mathrm{Ha}$ is rejected or there is no difference significant between the pretest results of the control class and the experiment class. Following are the results of the Pre-test hypothesis test for the control class and the experimental class (Table 3 ).

Table 3. T-Test Result Pre-Test Control Class and Experiment Class

\begin{tabular}{|l|c|c|c|c|c|}
\hline \multicolumn{1}{|c|}{$\begin{array}{c}\text { Learning } \\
\text { outcomes }\end{array}$} & $\begin{array}{c}\text { The } \\
\text { mean }\end{array}$ & $\begin{array}{c}\text { Std. } \\
\text { Deviation }\end{array}$ & $t_{\text {count }}$ & $t_{\text {table }}$ & Description \\
\hline Control class & 71.3667 & 8.07928 & \multirow{2}{*}{0.214} & 2.00172 & $\begin{array}{c}\text { Ho } \\
\text { Received }\end{array}$ \\
\hline $\begin{array}{l}\text { Experiment } \\
\text { Class }\end{array}$ & 71.8 & 7.61758 & 0.21 & & \\
\hline
\end{tabular}

Based on the test results above obtained values $t_{\text {count }}<t_{\text {table }}$ that is 0.214 $<2.00172$ so it can be concluded that there is no significant difference between the results of the pre-test control class and the experiment class. The values of the average control class and experiment class are 71.3667 and 71.8 .

b) T-Test Post-Test Control Class and Experiment Class

The hypothesis used in this test is:

$\mathrm{Ha}$ : There is a significant difference between the results of the pre-test control class and the experiment class

Ho : There is no significant difference between the results of the pre-test control class and the experiment class

If the value of tcount $\geq$ from ttable, then $\mathrm{Ha}$ is accepted and Ho is rejected or there is a significant difference between the results of the post-test of the control class and the experiment class while if the value of tcount $\leq$ of ttable then Ho is 
accepted and $\mathrm{Ha}$ is rejected or there is no difference significant between the post-test results of the control class and the experiment class. Following are the results of the Post-test hypothesis test of the control class and the experiment class (Table 4).

Table 4. T-Test Result Post-Test Control Class and Experiment Class

\begin{tabular}{|c|c|c|c|c|c|}
\hline $\begin{array}{l}\text { Learning } \\
\text { outcomes }\end{array}$ & Mean & \begin{tabular}{|c|} 
Std. \\
Deviation
\end{tabular} & $t_{\text {coumt }}$ & $t_{\text {table }}$ & Description \\
\hline Control class & 71,3667 & 5,96821 & \multirow[b]{2}{*}{6,122} & \multirow[b]{2}{*}{2,00172} & \multirow[b]{2}{*}{$\begin{array}{c}\text { Ho } \\
\text { Rejected }\end{array}$} \\
\hline $\begin{array}{l}\text { Experimentation } \\
\text { Class }\end{array}$ & 80,7333 & 5,8834 & & & \\
\hline
\end{tabular}

Resource: Primary data that has been processed

According to the table above were obtained by value $t_{\text {count }} \geq t_{\text {table }}$ is $6.122 \geq 2.00172$ it can be concluded that there are significant differences between the results of post-test control group and the experiment class. The value of the average grade control and the experiment class is 71.3667 and 80.7333 , so the hypothesis can be stated there is an increase significant for the application of Cooperative Learning Model in Jigsaw Type of the basic accounting of the learning outcomes of $\mathrm{X}$ Accounting Graders at SMK 1 Depok.

\section{CONCLUSION AND SUGGESTION Conclusion}

a) Learning outcomes of Basic Accounting subject before applied learning models Cooperative Learning type Jigsaw in class X Accounting at SMK Negeri 1 Depok Yogyakarta result the average value of the pre-test the control class is 71.367 with the highest score of 90 and the lowest value of 50. From the results of the control class pre-test scores totaling 30 students there were 21 students whose grades were below the KKM, and 9 students reached the KKM. While the results of the value of the average pre-test in experimental class at 71.8 with the highest score of 90 and the lowest value of 50. From the results of the acquisition value of the pre-test to the welding experiment totaling 30 students there are 21 students who value is less $\mathrm{KKM}$, and 9 students who achieve KKM.

b) Learning Outcomes of Basic Accounting Subject after applied learning models Cooperative Learning type Jigsaw in class X SMK Negeri 1 Depok Yoogyakarta gained an average of the results of the average value of the post-test on the control class is 71.433 with the highest score of 83 and the lowest value of 60 . The results of the control class post-test scores were 21 students whose grades were below the KKM and 9 students who achieved the KKM. While the average value of the results of the post-test on experiment class at 80.733 with a high of 90 and low of 67. Results value acquisition value of the post-test experimental class there are 4 students whose grade under the KKM and as many as 26 students who achieve KKM.

c) There is increase of learning outcome after use of the learning model Cooperative Learning type Jigsaw of Basic Accounting to students in class $\mathrm{X}$ at SMK Negeri 1 Depok Yogyakarta. It can be seen from the results of hypothesis testing $\mathrm{t}$-test showed that significant values obtained on the value of the pre-test control class and experimental class $0.213<2.00172$ or $t$ count $<\mathrm{t}$ table, then we can conclude that there are significant differences between control class and experimental class pre-test results. While the value of the post-test class of the control class and the experimental class obtained data $6.122 \geq 2.00172$ or $\mathrm{t}$ count $\geq \mathrm{t}$ table, it can be concluded that there are significant differences between the results of the control class and experimental class post-test so that it is 
stated there is a significant increase in the application Cooperative Learning model Jigsaw type in Basic Accounting subjects to the learning outcomes of class $\mathrm{X}$ students at SMK Negeri 1 Depok Yogyakarta.

\section{Suggestion}

a) For Teacher

1) Teachers need to provide motivation and enthusiasm for students so they can build student interest in learning Basic Accounting subjects.

2) The application of learning models in a variety of ways makes the classroom atmosphere not monotonous and boring so that it can improve students abilities in mastering learning material.

3) Based on the research model of learning Cooperative Learning type Jigsaw showed that the learning model used has a significant effect on improving student learning outcomes in subjects Basic Accounting.

b) For Student

1) Students abilities, both cognitive abilities, affective abilities, and psychomotor abilities can be improved through the applied cooperative learning model. The cooperative learning model can increase knowledge, train students to be responsible, be active in learning activities, be independent and respect others.

2) Students are expected to be more active in participating in learning activities so that material that is perceived to be less understood can be discussed first.

\section{REFERENCES}

Depdiknas. (2003). Undang-Undang Nomor 20 tentang Sistem Pendidikan Nasional.
Isjoni. (2010). Pembelajaran Kooperatif Meningkatkan Kecerdasan Komunikasi Antar Peserta Didik. Yogyakarta: Pustaka Pelajar.

Jakni. (2016). Metodologi Penelitian Eksperimen Bidang Pendidikan. Bandung: Alfabeta.

Juweto G.A. (2015). Effects of Jigsaw Cooperative Teaching/Learning Strategy and School Location on Students Achievement and Attitude Towards Biology in Secondary School in Delta State. International Journal of Education and Research. 3(8): 31-40.

Mehta, Sonam dan A. K. Kulshrestha. (2014). Implementation of Cooperative Learning in Science: A Developmental-cum-Experimental Study. Hindawi Publishing Corporation Education Research International. 2014: 1-7.

Miftahul Huda. (2012). Cooperative Learning Metode, Teknik, Struktur dan Model Terapan. Yogyakarta: Pustaka Pelajar.

Nikmah Khoiroh (2011). Efektivitas Model Pembelajaran Kooperatif Tipe Jigsaw Berbantuan Macromedia Flash Terhadap Prestasi Belajar Siswa Kelas XI IPS Mata Pelajaran Akuntansi Pokok Bahasan Jurnal Penyesuaian di SMK N 2 Ungaran Tahun Ajaran 2010/2011. Abstrak Hasil Penelitian. Jawa Tengah: UNNES.

Rahayu, Cici Marlina. (2017, 23 Maret). JPPI: Indeks Pendidikan Indonesia di Bawah Ethiopia dan Filipina. Diperoleh 21 Februari 2019, dari https://news.detik.com/berita/d3454712/jppi-indeks-pendidikan- 
indonesia-di-bawah-ethiopia-danfilipina.

Rifai, Muhammad. (2011). Sosiologi Pendidikan. Yogyakarta: Ar-Ruzz Media.

Riskiyah (2017). Pengaruh Model Pembelajaran Cooperative Learning Tipe Jigsaw Pada Mata Pelajaran Dasar Desain Terhadap Hasil Belajar Siswa Kelas X di SMK N 3 Klaten. Abstrak Hasil Penelitian. Yogyakarta: UNY.

Riyanto, Yatim. (2010). Paradigma Baru Pembelajaran Sebagai Referensi Bagi Guru/Pendidik Dalam Implementasi Pembelajaran yang Efektif dan Berkualitas. Jakarta: Kencana Prenada Media Group.

Robert E. Slavin. (2014). Cooperative Learning and Academic Achievement: Why Does Groupwork Work? Anales de Psicologia. 30(3): 785-791.

Shan Ying Chu. (2014). Application of the Jigsaw Cooperative Learning Method in Economics Course. International Journal of Managerial Studies and Research (IJMSR). 2(10): 166-172.
Slavin, Robert E. (2005). Cooperative Learning (Cara Efektif dan Menyenangkan Pacu Prestasi Seluruh Peserta Didik). Bandung: Nusa Media.

Sugianto. (2010). Model-Model Pembelajaran Inovatif. Surakarta: Yuma Pustaka.

Tri Yudono (2016). Perbedaan Model Pembelajaran Kooperatif Tipe Jigsaw dan STAD Terhadap Prestasi Belajar Siswa Pada Mata Pelajaran Pemeliharaan Kelistrikan Kendaraan Ringan Kelas XI Jurusan Otomotif SMK Negeri 2 Wonosari Tahun Pelajaran 2015/2016. Abstrak Hasil Penelitian. Yogyakarta: UNY.

Ummi Rosdiyah. (2016, Desember). Pengaruh Model Pembelajaran Kooperatif Tipe Jigsaw Terhadap Hasil Belajar Matematika Siswa Kelas VIII SMP Negeri 6 Metro. Jurnal SAP, Vol. 1, No. 2, 115-124. Diambil dari https://journal.lppmunindra.ac.id/ind ex.php/SAP/article/download/1018/9 99. 